\title{
Cryoseston of the Pirin Mountains, Bulgaria
}

\author{
VLADISLAV CEPÁK* , JAROMÍR LUKAVSKÝ \\ Academy of Sciences of the Czech Republic, Institute of Botany, Centre of Algology, \\ Dukelská 135, CZ-37982 Třeboň, Czech Republic
}

\begin{abstract}
In the cryoseston community of the Pirin Mountains, 18 species were determined. Chlorophyta: Chlamydomonas nivalis (predominant), Chloromonas brevispina, Chloromonas rostafinski, Chlainomonas rubra (new genus and species for Bulgaria, documented in Europe for only the second time), Cystococcus nivicolus and Stichococcus nivalis. Bacillariophyceae: Aulacoseira granulata var. angustissima, Hantzchia amphioxys, cf. Surirella. Fungi: cf. Chytridium chlamydococcii. Deuteromycetes: Selenotila nivalis, Chionaster nivalis, and saprophytic fungae cf. Myzocytium, Rhodosporidium toruloides, Alternaria sp. and cf. Cladosporium, in pollen grains. Bacteria: Leptothrix ochracea. Ciliata: Vorticella campanula. The composition of cryoseston in the Pirin Mountains is characteristic for high mountains where Chlamydomonas nivalis predominates.
\end{abstract}

Key words: Chlainomonas rubra, cryoseston, Pirin Mountains, snow algae, Bulgaria

\section{Introduction}

Extremophilic algae are attracting attention as a prospective pool of organisms producing compounds of biotechnological interest (HoHAm and Duval 2001, Pulz and Gross 2004, SecKBach 2007, ŘEzAnKa et al. 2008). The cryosestonic alga Chlamydomonas nivalis produces large amounts of the red pigment, astaxanthin, which is an effective UV screen and, as a free radical acceptor, protects cells against photoinhibition (REMIAS et al. 2005, ŘEZANKA et al. 2007). Moreover $C$. nivalis is not a strict cryophile as photosynthetic activity continued up to $20^{\circ} \mathrm{C}$ for about one hour (REMIAS et al. 2005), as was the case with the mesophile Haematococcus pluvialis (WANG et al. 2003). Recently C. nivalis was patented for use in cosmetics as a UV filter (BROOKS and FrANKLIN 2011, SCHÜRCH et al. 2010).

In addition, cryosestonic algae contain anti-freeze proteins (AFP) that bind to small ice crystals in cells and permit the survival of cells at temperatures below zero (LI et al. 2009, GWAK et al. 2010). For space research (astrobiology), cryoseston is used as an analogy for e.g. Martian life (Wharton et al. 1989, RothschiLd 1990, KANIK 2009).

\footnotetext{
* Corresponding author, e-mail: cepak@botany.cas.cz

Copyright $^{\circledR} 2013$ by Acta Botanica Croatica, the Faculty of Science, University of Zagreb. All rights reserved.
} 
The first step towards the biotechnological exploitation of cryophilic algae is sample collection, cell isolation and screening. A checklist of species is built up via such research. In Bulgaria, cryoseston was recorded for the first time by KoL (1956) in the Rila Mountains, and in the Pirin Mountains. This report was confirmed by WodEnITSCHAROFF (1962) in the Rila Mountains and new localities were found later by LUKAVSKÝ et al. (2009) in the Vitosha Mountains, and Stara Planina Mountains (LuKAVsKÝ and CEPÁK 2010).

The aim of this work was to confirm the species diversity in the locality of the Pirin Mountains and to isolate strains for further research.

\section{Material and methods}

\section{Localities}

Snow fields were sampled in the Pirin Mountains at altitudes of 1996-2930 m a.s.l., in May, 2011 (Tab. 1).

Tab. 1. GPS positions, altitudes and species presence in individual localities. $d=$ dominant species.

\begin{tabular}{|c|c|c|c|c|c|c|c|c|c|c|c|c|c|c|c|}
\hline No. & 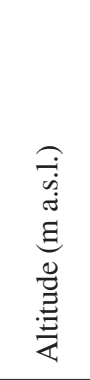 & GPS & 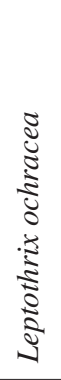 & 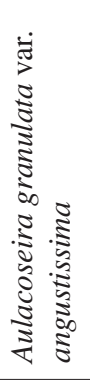 & 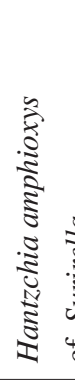 & 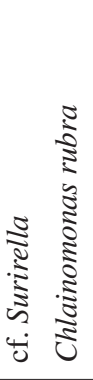 & 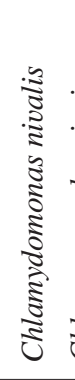 & 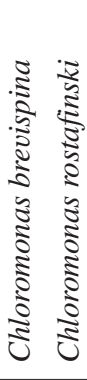 & 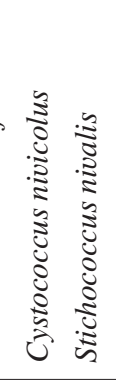 & 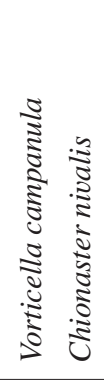 & 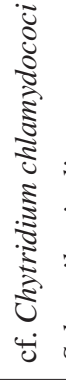 & 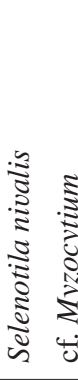 & 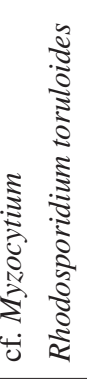 & 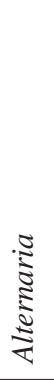 & 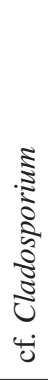 \\
\hline 47 & 1996 & $\begin{array}{l}\text { N41 } 52.672 \\
\text { E23 } 31.782\end{array}$ & & $\mathrm{x}$ & & & & & & & & $\mathrm{x}$ & $\mathrm{x}$ & $\mathrm{x}$ & \\
\hline 44 & 2118 & $\begin{array}{l}\text { N41 } 45.641 \\
\text { E23 } 24.570\end{array}$ & & & $\mathrm{x}$ & $\mathrm{x}$ & & $\mathrm{x}$ & & & $\mathrm{x}$ & $\mathrm{x}$ & $\mathrm{x}$ & & \\
\hline 48 & 2379 & $\begin{array}{l}\text { N41 } 45.619 \\
\text { E23 } 24.346\end{array}$ & $\mathrm{x}$ & & & $\mathrm{x}$ & $\mathrm{d}$ & & & $\mathrm{x}$ & $\mathrm{x}$ & & & & \\
\hline 46 & 2426 & $\begin{array}{l}\text { N41 } 45.588 \\
\text { E23 } 24.248\end{array}$ & & & & & $\mathrm{~d}$ & $\mathrm{x}$ & & & & & & & $\mathrm{x}$ \\
\hline 45 & 2483 & $\begin{array}{l}\text { N41 } 45.614 \\
\text { E23 } 24.110\end{array}$ & & & & & & & $\mathrm{x}$ & $\mathrm{x}$ & & & & & \\
\hline 49 & 2483 & $\begin{array}{l}\text { N41 } 45.608 \\
\text { E23 } 24.177\end{array}$ & & & & & & & & & & & & & \\
\hline 41 & 2549 & $\begin{array}{l}\text { N41 } 45.649 \\
\text { E23 } 23.984\end{array}$ & & & & & $\mathrm{x}$ & $\mathrm{x}$ & & $\mathrm{x}$ & & $\mathrm{x}$ & $\mathrm{x}$ & & \\
\hline 43 & 2729 & $\begin{array}{l}\text { N41 } 45.826 \\
\text { E23 } 23.883\end{array}$ & & & & & $\mathrm{x}$ & & & & & & & & \\
\hline 42 & 2930 & $\begin{array}{l}\text { N41 } 46.036 \\
\text { E23 } 23.942\end{array}$ & & & & & & & & & & $\mathrm{x}$ & & & \\
\hline
\end{tabular}




\section{Sampling and sample processing}

Snow samples were collected into plastic bags, in volumes of ca $20 \mathrm{~mL}$, transported in a thermos bottle to the laboratory, melted, centrifuged for $20 \mathrm{~min}$. at $3000 \mathrm{~g}$, at temperatures below $5^{\circ} \mathrm{C}$, examined with the use of an Olympus DX 50 microscope and photographed using a DP10 digital camera. Autofluorescence of chlorophyll was observed under the same microscope, equipped with a filter combination of 360-370 $\mathrm{nm}$ excitation, $>515 \mathrm{~nm}$ barrier filter. Samples were inoculated into medium Z (STAUB 1961)-containing tubes, solidified with $2 \%$ agar, and held in a refrigerator at a temperature of less than $7{ }^{\circ} \mathrm{C}$ with continuous irradiation from fluorescent tubes (ca $20 \mathrm{~W} \mathrm{~m}^{-2}$ PAR). The selected strains are maintained in the Collection of Biotechnological Exploitable Microorganisms (COBIEM) in Třeboň (Czech Republic).

\section{Results and discussion}

In snow samples from the Pirin Mountains, we isolated and identified 18 microorganisms (Pl. 1-4, Figs. 1-56).

\section{Chlorophyta}

Chlainomonas rubra (J. R. Stein et R. C. Brooke) Hoham, Pl. 1, Figs. 1-8.

Syn. Sphaerellopsis rubra Stein et Brooke 1964

Description: Cells egg-shaped, about $30 \times 50 \mu \mathrm{m}$, sometimes with a small, but prominent papilla, flagella not observed. Cell wall smooth, outer and inner envelopes separated by a wide space. Protoplast contents brown, filled by small grains, pyrenoid not observed. Division into 2 autospores is predominantly unequal.

Distribution: Chlainomonas rubra and C. kolii were identified only from snow. C. kolii was described as a snow alga by Нонам (1974a), who re-arranged Trachelomonas kolii (Euglenales) into Chlorophyta, as Chlainomonas kolii. This same alga was described in snow samples from Canada, in the NW Pacific Mountains of the USA, and in Mt Philistine, New Zealand (Novis 2002, Novis et al 2008). Chlainomonas rubra (HoHAM 1974b) was identified in snow in Tirole, N. Island of New Zealand, the Pacific Northwest USA, Wenatchee Natl For., Washington, and Mt. Seymour Park, Brit. Columbia, Canada (Novis et al. 2008). It represents a new genus and species for the Bulgarian algal database, and this is only the second documented record in Europe. Cf. Chlainomonas was also identified in Central Svalbard (KvíDEROVÁ 2012).

Notes: Type of the genus is $C$. ovalis H. R. Christen. The monophyly of the genus Chlainomonas was proven by DNA analysis. It is the only quadriflagellate chlorophycean unicell that shares a robust affinity to biflagellates. Maybe Chlainomonas was derived from the fusion of biflagellate cells or is a diploid component of a biflagellate phase (sexual reproduction was not seen). The flagellar basal apparatus was also organized into two distinct pairs of basal bodies that lack connections (Novis et al. 2008). The alga is very sensitive to temperature, and can only live at $0-4{ }^{\circ} \mathrm{C}$ (НонAм 1975). Perhaps for this reason we have not yet been able to culture this organism. The colour of the alga found in the Pirin Mountains is very unusual. While cells of $C$. rubra and $C$. kolii are a pink-red colour, while our material was more brown (Fig. 7). The pigment composition could be unique. 


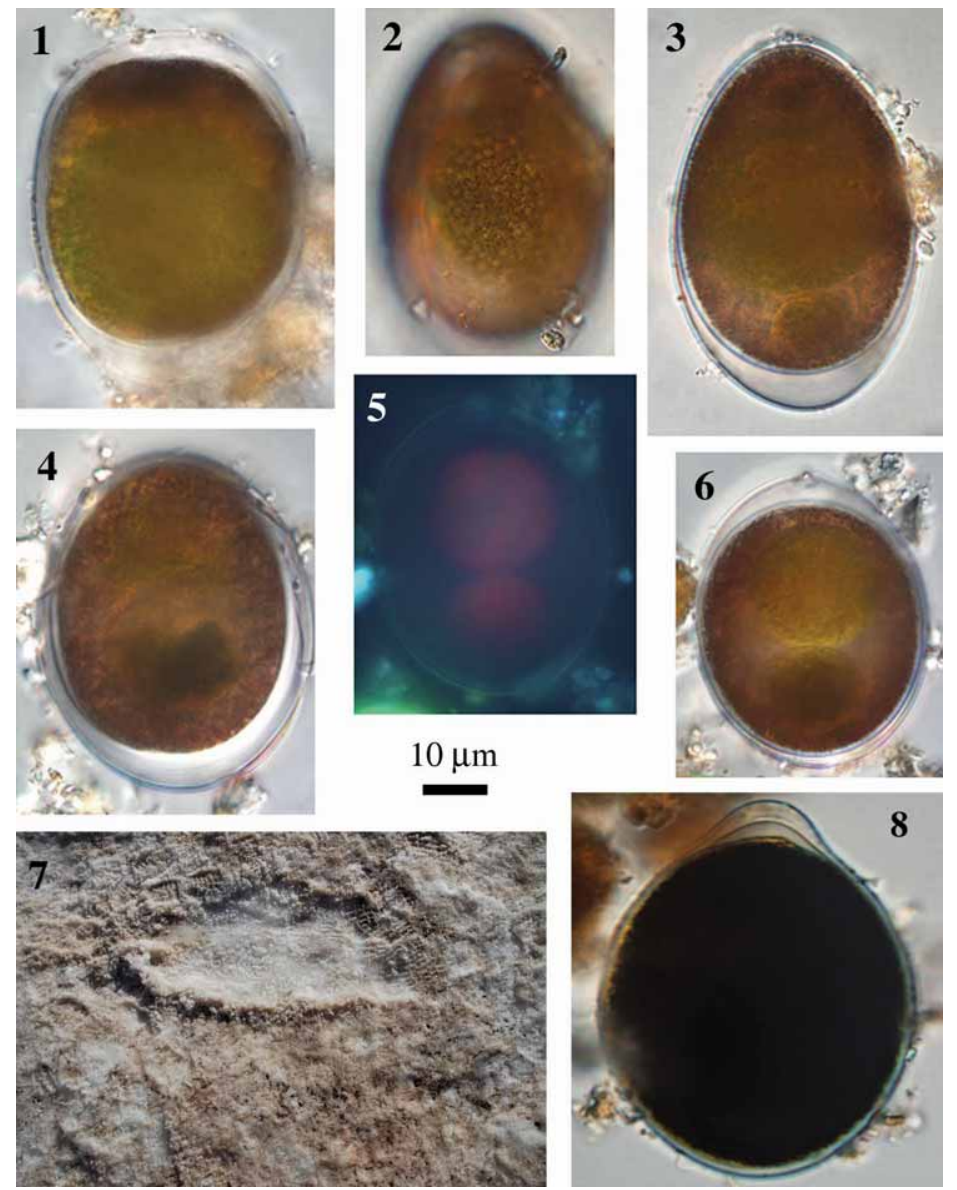

Plate 1. Cryoseston of the Pirin Mountains. collected in May 2011. Figs. 1-4-Chlainomonas rubra, protoplast filled with a mass of small grains; $\mathbf{5}$ - Autofluorescence of chlorophylls under UV irradiation; 6 - Division of protoplast into 2 unequal parts (note small, but prominent papilla); 7 - Coloured snow at locality no. 44 (algae are near the surface); 8 - Outer envelope (cell wall), showing distance from inner envelope (stained with Lugol solution), see also figures $\mathbf{3}$, 4 and 6. All figures loc. 44.

Chlamydomonas nivalis (Bauer) Wille, Figs. 9-14, 19-22.

Syn. Uredo nivalis Bauer, Sphaerella nivalis (Bauer) Sommerfelt, Protococcus nivalis Agardh, Haematococcus nivalis Flotow

Description: Only spherical spores/hypnoblasts, deep-red coloured, diameter 35-40 $\mu \mathrm{m}$, some in an envelope of dust grains of different thicknesses. Division has not yet been observed. In adult cells, chloroplasts are split into a few disc-shaped parts (Figs. 11, 21), in agreement with REMIAS et al. (2005).

Notes: The characteristically brick-red colour of protoplasts is caused by astaxanthin and its fatty acid esters. This compound protects the alga from damage by UV irradiation. The first screen is a cover made up of inorganic dust particles that stick to the mucilage layer 
(REMIAS et al. 2005). This dust envelope is of different thicknesses (Figs. 19, 20, 22). Fatty acids, together with haematochromes, also protect cells from freezing. $C$. nivalis is characteristic at higher altitudes, open stands and under strong irradiation (KAWECKA 1981, HOHAM et al. 1993). Surprisingly, photosynthesis proceeds up to $20^{\circ} \mathrm{C}$ (but only in short-term experiments of about one hour), proving that the alga is more cryotolerant than cryophilic. In
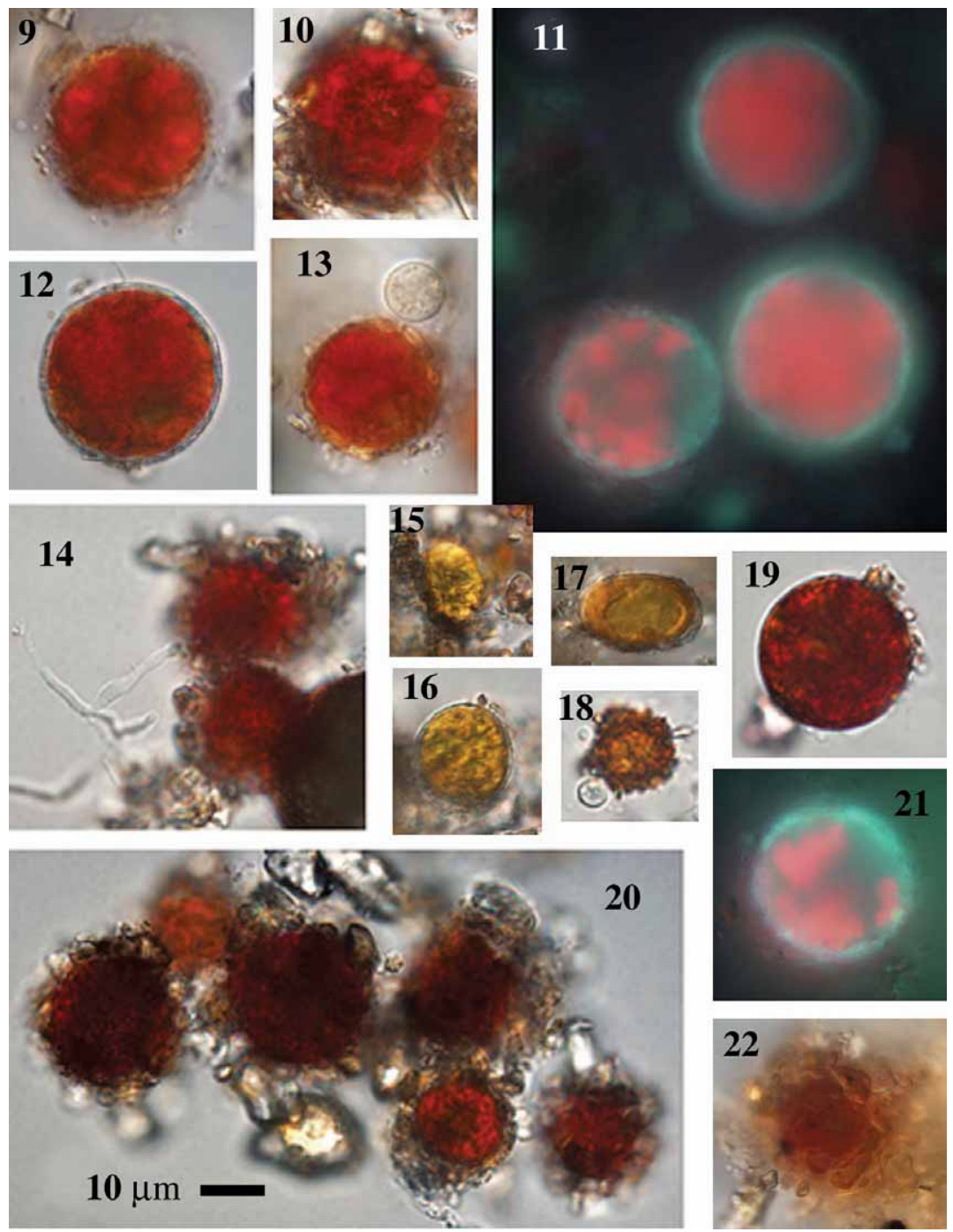

Plate 2. Cryoseston of the Pirin Mountains collected in May 2011. Figs. 9-14, 19-22 - Chlamydomonas nivalis; 11, 12, 21 - fluorescence of chlorophyll under UV irradiation; 13, 18 - cells infected by some chytrid, cf. Chytridium chlamydococci; $\mathbf{1 4}$ - cells infected by some filamentous fungus, Selenotila nivalis; 15-18 - Chloromonas brevispina. Loc. 41: figures 14-16, 19; Loc. 43: figures 22; Loc. 44: figures17, 18; Loc. 46: figure 20; Loc. 48: figures 9-13, 21. 
addition, in drying experiments, the hypnospore showed high viability after storage at room temperature for 6 months (REMIAS et al. 2005). All the physiological characteristics demonstrate that this species has a potential for biotechnological exploitation.

Chloromonas brevispina (Fritsch) Hoham, Roemer et Mullet, Figs. 15-18.

Syn. Chodatella brevispina Fritsch, Cryocystis brevispina (Fritsch) Kol

Description: Cysts ellipsoidal, $15 \times 20 \mu \mathrm{m}$, cell wall thick, smooth (Fig. 17) or covered with small protrusions, cell content green or orange (Fig. 17). Sometimes cells were covered with dust grains (Figs. 15, 18), pyrenoid was not observed.

Notes: Chloromonas brevispina and Chloromonas rostafinski are very similar in morphology, cell structure, and reproduction, and both are snow algae. Some differences in size and in spines/blunt protrusions can be the result of growth conditions, including nutrients (KaWECKa 1983/84, Kawecka and Eloranta 1986, HoHam et al. 1979).

Chloromonas rostafinski (Starmach et Kawecka) Gerloff et H.Ettl, Figs. 23-25, 28-29, 33.

Syn. Chlamydomonas rostafinski Starmach et Kawecka

Description: Cysts ellipsoid, $12 \times 25 \mu \mathrm{m}$; cell wall uniformly covered with papillae-like structures; cell contents green or orange; chloroplast without a pyrenoid. Flagellate stages (Figs. 25, 29) observed.

Notes: Chloromonas rostafinski was described by STARMACH and KAWECKA (1965) as Chlamydomonas rostafinski, isolated from yellowish-green snow in the alpine zone of the High Tatra Mountains (KawECKA 1983/84, LuKAVSKÝ 1994) and later in the Stara Planina Mountains (LUKAVSKÝ et CEPÁK 2010). Its characteristic structure was revealed by SEM (KAWECKA and ELORANTA 1986). It is covered by numerous longitudinal ribs that feature indentations of different lengths, forming papilla-like structures visible by light microscopy. These non-motile cells are believed to be formed (probably asexually) from vegetative cells through gradual development of cell wall ornamentation.

We also observed similar cells with a smooth, or almost smooth cell wall, and pink oil droplets near both poles (Fig. 17) resembling Cryodactylon japonica Kol. We suppose that these cells could be immature stages of Chloromonas rostafinski or Chloromonas brevispina resting cells. KAWECKA and ELORANTA (1986) recorded cells of Chloromonas rostafinski with ornamentation of the cell wall developed to varying degrees, and stated that they were stages of growth of resting cells. Further culture studies, under different conditions, are necessary.

Stichococcus nivalis Chodat, Fig. 32

Description: Cells rod-shaped, $5 \times 10 \mu \mathrm{m}$, arranged in short or longer, but not firm filaments.

Notes: Stichocccus nivalis is described mainly as individual cells or as very short filaments (Kol 1968), but the alga described here was mainly in longer filaments.

\section{Cystococcus nivicolus Kol, Fig. 38}

Description: Cells spherical, $15 \mu \mathrm{m}$ in diameter, cell wall smooth, chloroplast central, with many irregular lobes, and a prominent median pyrenoid. Under the cell wall ring are 

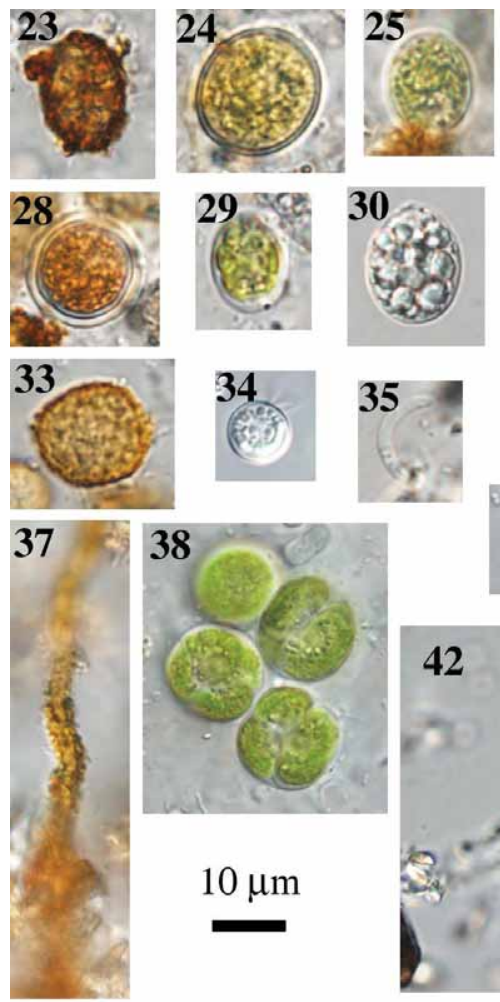

38

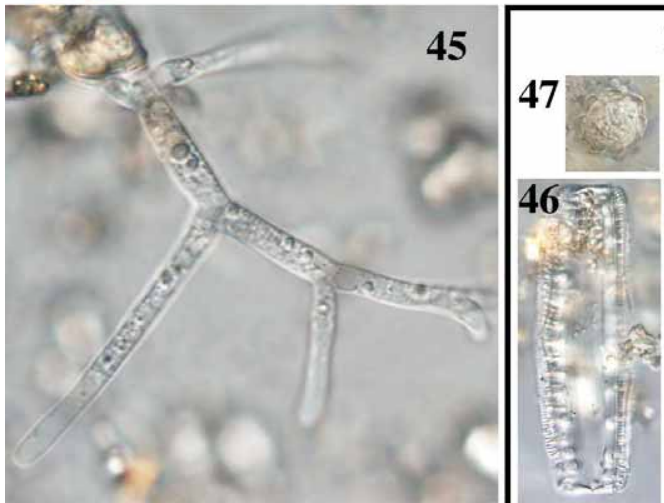

$10 \mu \mathrm{m}$
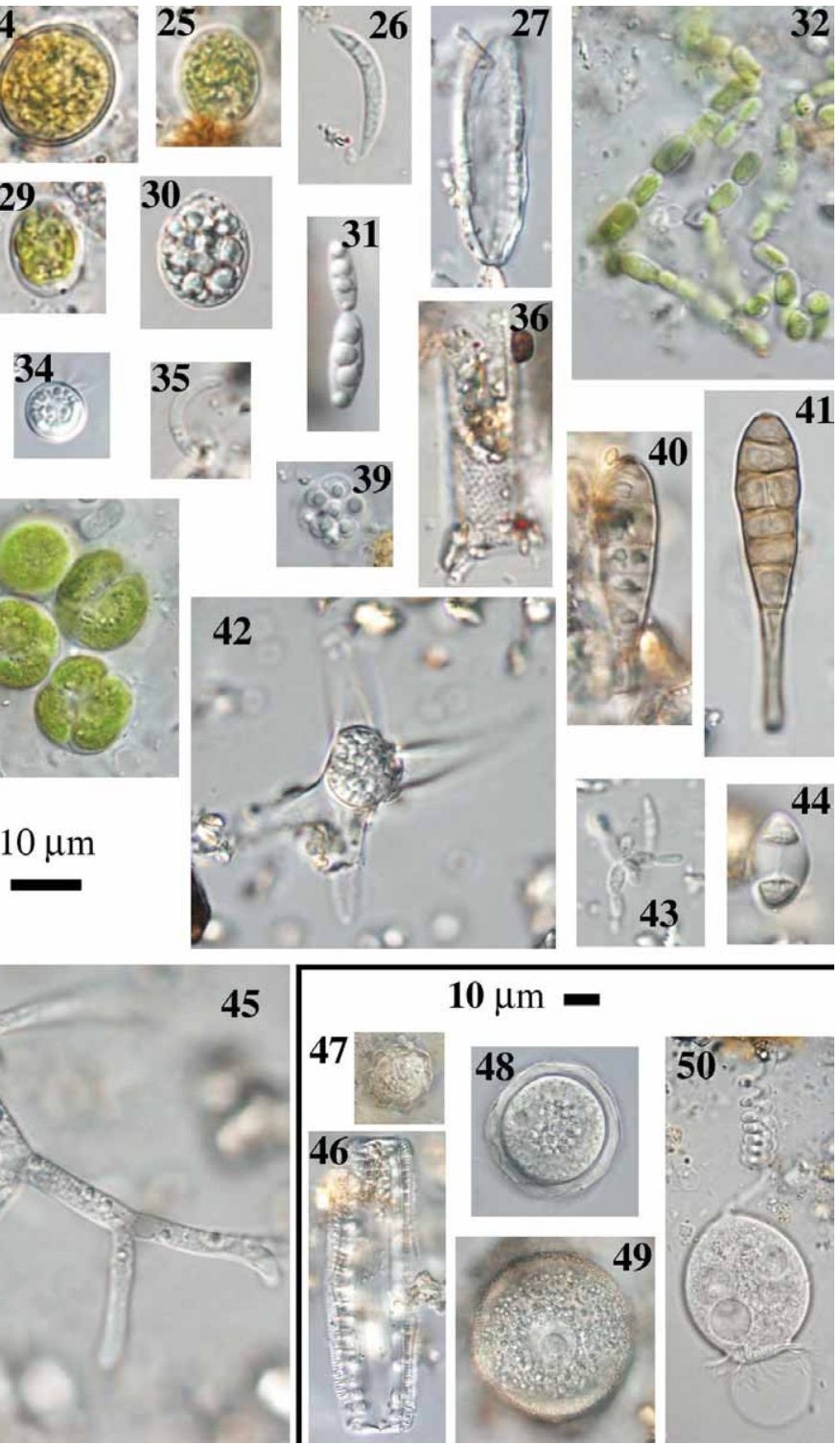

Plate 3. Cryoseston of the Pirin Mountains collected in May 2011. Figs. 23-25, 28-30, 33 - Chloromonas rostafinski; $\mathbf{2 5}$ - zoospore; $\mathbf{3 0}$ - zoospore or a colourless flagellate; 26, 31, 35, 43 Selenotila nivalis; 27 - Hantzchia amphioxys; 32 - Stichococcus nivalis; $\mathbf{3 4}$ - unknown organism; 36-Aulacoseira granulata var. angustissima; 37 - Fe bacteria Leptothrix ochracea; 38 - Cystococcus nivicolus; 39 - mature sporangium of some Chytridiomycet, cf Chytridium chlamydococci, see also figures 13,18 - sporangia with characteristic oil drops; 40, 41 spores of Alternaria (Deuteromycetes); $\mathbf{4 2}$-Chionaster nivalis; $\mathbf{4 4}$ - spore of Deuteromycete cf. Cladosporium; 45 - a filamentous fungus; 46 - cf. Surirella; 47-50 - Vorticella campanula (47-49 cysts, $\mathbf{5 0}$ - mature organism). Loc. 41: figures 26, 42; Loc. 42: figures 31, 34; Loc. 44: figures 23-25, 27-30, 33, 35; Loc. 45: figures 32, 38, 39, 47-50; Loc. 46: figures 28, 44; Loc. 47: figures 36, 40, 41, 43; Loc. 48: figures 37, 46, 47. 
numerous, peripheral small vacuoles, between the lobes of the chloroplast. Reproduction was by 2, 4 (8) autospores.

Notes: Kol (1956) determined the species in the Rila Mountains and placed it into Chlorophyta (Chlorococcales), proving the classification by observation of zoospores with 2 equal flagella. In our material, green as well as yellow-green cells and only autospores were seen. Zoospores in figures 25 and 29 are probably the products of Chloromonas rostafinski. For further study, isolation of unialgal culture will be necessary.

\section{Bacillariophyceae}

Aulacoseira granulata var. angustissima (O. F. Müll.) Simonsen, Fig. 36

Syn. Melosira granulata var. angustissima (O. F. Müll.) Hust.

This species was found only in the form of dead frustulae, but our identification of living cells of identical species in snow from a few other localities e.g. the Stara Planina Mountains, Bulgaria (LuKAVSKÝ and CEPÁK 2010) and the Sierra Nevada Mountains, Spain (CEPÁK and LUKAVSKÝ 2012) proved that they are not accidental, but are true cryobionts.

Hantzchia amphioxys (Ehrenb.) Grun., Fig. 27

Dead frustulae of the species were determined in a few localities, as with previous species.

\section{Fungi}

cf. Chytridium chlamydococci A. Braun f. cryophila Kol., Figs. 13, 18, 39

Description: Sporangia globular 7-12 $\mu \mathrm{m}$ in diam. No papilla or intercellular components were observed.

Notes: A few individual cells of Chlamydomonas nivalis were infected by some chytrid (Figs. 13, 18). Also figure 39 probably shows a cluster of zoospores, with characteristic oil droplets, after being released from the sporangium. For exact determination, we need details of intracellular components of the fungus (rhizoid - single or branched, hausotrium etc.).

Chytridium chlamydococci was described as a parasite of Chlamydococcus pluvialis. It was also described as Rhizophydium acuforme (Zopf) Fischer by LETCHER and POwELL (2012). Rhizophydium acuforme has been observed several times, as common parasites of moving Chlamydomonas cells (LETCHER and POWELL 2012, LuKAVSKÝ 1970). In cryoseston, Kol (1968) established that similar organisms such as Chytridium chlamydococcii f. cryophila were common parasites of Chlamydomonas nivalis. It has been found globally in Europe, America etc.

Characteristic features of Rhizophydium acuforme are few sporangia/host cell, adult sporangia have prominent papilla, rhizoid is branched into a few parts, zoospores with a prominent oil droplet and a long flagellum, thick-walled spores are rounded. Relationships betweenthe two organisms are unknown and further study is necessary.

Chionaster nivalis (Bohl.) Wille, Fig. 42

This fungus is a common species of cryoseston. In Bulgaria, it was identified for the first time in the Pirin Mountains (Kol 1956) and in the Vitosha Mountains (LuKAVSKÝ et al. 2009). It is recognized as »nomen dubium« (ARX et al. 1977, KIRK et al. 2001). 


\section{cf. Myzocytium, Figs. 51-54, 56}

Description: Thallus thick, tube-like, later as a chain of rounded elongated blue cells, reproduction not seen. Saprophytic fungus, decaying pollen grains.

Notes: Myzocytium is a common parasite of living algae, especially Conjugatophyceae, e.g. Micrasterias (BАTKO 1975), and it was identified in snow for the first time. For a precise identification, it would be necessary to observe its reproduction. Phycomycetes, particularly Chytridiomycetes, are recognized as the principal organisms causing the degradation of pollen grains (GOLDSTEIN 1960). In cryoseston, pollen grains were found, but their decomposition has not yet been studied thoroughly.
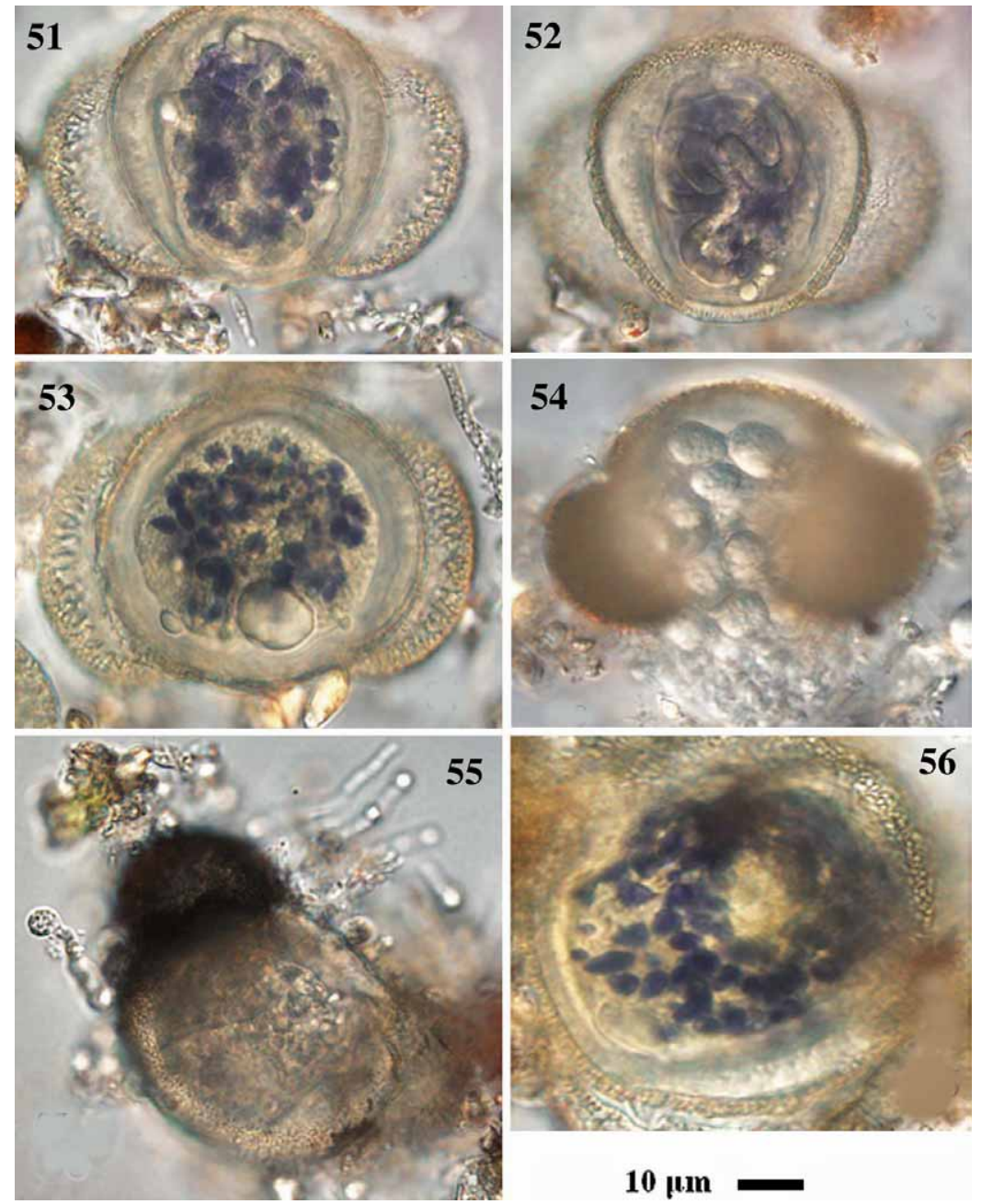

Plate 4. Cryoseston of the Pirin Mountains collected in May 2011. Figs. 51-54, 56 - saprophytic chytrid cf. Myzocytium in pollen grains of Pinus peuce; 55 - fungus Rhodosporidium toruloides. Material was not stained with Lugol solution. Loc. 41: figure 55; Loc. 44: figure 54; Loc. 47: figures 51-53, 56. 


\section{Rhodosporidium toruloides, Fig. 55}

Yeast, a saprophyte in pollen grains, was identified in snow for the first time. For a precise identification, further observations are necessary. Fungi and bacteria grow in the mucilage surrounding some species, e.g. Chlamydomonas nivalis, but knowledge about them is fragmentary (REMIAS et al. 2005).

\section{Ciliata}

Vorticella campanula Ehr., Figs. 47-50

Description: Characteristic bell-shape cells, $30 \times 40 \mu \mathrm{m}$, seated on a spiral, contractile long stalk. Figures 47 and 48 probably show cystic forms that enable survival in unfavourable conditions.

Notes: Ciliata have been occasionally described as members of cryoseston, but published reports are scarce (HoHAm et Duval 2001). Usually, Vorticella are found in eutrophic-polytrophic waters. A characteristic feature of this species is a mass of highly refractile, small reserve grains.

\section{Acknowledgements}

This work was supported as a project of the Technology Agency of Czech Republic TE 01020080 and TA03011027 and by the institutional long-term research plan no. AV0Z60050516, funded by the Academy of Sciences of the Czech Republic. We also thank the exchange programme of the Bulgarian Academy of Sciences, the Institute of Plant Physiology and Genetics, Sofia, for assistance, H. Brabcová who participated in technical affairs, and J.D. Brooker who kindly corrected the English.

\section{References}

Arx, J. A., Miranda, R., Smith, M. T., Yarrow, D., 1977: The genera of yeasts and the yeast-like fungi. Study in Mycology 14, 12-78.

BAтKo, A., 1975: Introduction to hydromycology (In Polish). Wydawnictwo Naukowe PWN, Warszawa.

Brooks, G. R., Franklin, S., 2011: Cosmetic composition comprising microalgal components. Patent US 2011/0250178 A1.

Cepák, V., Lukavský, J., 2012: Cryoseston in Sierra Nevada Mountains (Spain). Nova Hedwigia 94, 163-173.

Goldstein, S., 1960: Degradation of pollen by Phycomycetes. Ecology 41, 543-545.

GwAK, G., Jung, W., KIM, H. J., KAnG, S. H., Jin, E. S., 2010: Antifreeze protein in Antarctic marine diatom, Chaetoceros neogracile. Marine Biotechnology 12, 630-639.

HoHAM, R. W., 1974a: Chlainomonas kolii (Hardy et Curl) comb. nov. (Chlorophyta, Volvocales), a revision of the snow alga, Trachelomonas kolii Hardy et Curl (Euglenophyta, Euglenales). Journal of Phycology 10, 392-396.

Hoнам, R. W., 1974b: New findings in the life history of the snow alga, Chlainomonas rubra (Stein \& Brooke) comb. nov. (Chlorophyta, Volvocales). Syesis 7, 239-247. 
HoHAM, R. W., 1975: Optimum temperatures and temperature ranges for growth of snow algae. Arctic Alpine Research 7, 13-24.

Hoham, R. W., Duval, B., 2001: Microbial ecology of snow and freshwater ice with emphasis on snow algae. In: Jones, H. G., Pomeroy, J. W., Walker, D. A., Hoham, R. W. (eds.), Snow ecology, 168-228. Cambridge University Press.

Hoham, R. W., Roemer, S. C., Mullet, J. E., 1979: Life history and ecology of the snow alga Chloromonas brevispina comb. nov. (Chlorophyta, Volvocales). Phycologia 18, 55-70.

Hoham, R. W., Laursen, A. E., Clive, S. O., Duval, B., 1993: Snow algae and other microbes in several Alpine areas in New-England. Proceedings 61 Annual Western Snow Conference, Quebec City, 165-173.

KANIK, I., 2009: Astrobiology of icy worlds. Retrieved February 11, 2013 from: http://astrobiology.nasa.gov/nai/library-of-resources/annual-reports/2009/jpl-icy-worlds/projects/ astrobiology-of-icy-worlds/

KAWECKA, B., 1981: Biology and ecology of snow algae. 2. Formation of aplanospores in Chlamydomonas nivalis (Bauer) Wille (Chlorophyta, Volvocales). Acta Hydrobiologica 23, 211-215.

KAWECKA, B., 1983/84: Biology and ecology of snow algae, 3. Sexual reproduction in Chloromonas rostafinski (Starmach and Kawecka) Gerloff and Ettl (Chlorophyta, Volvocales). Acta Hydrobiologica 25/26, 281-285.

KaWECKA, B., Eloranta, P., 1986: Biology and ecology of snow algae. SEM studies on the cell wall structure of »resting cells « of Chloromonas rostafinski (Starmach and Kawecka) Gerloff et Ettl (Chlorophyta, Volvocales). Acta Hydrobiologica 28, 387-391.

Kirk, P. M., CAnnon, P. F., David, J. C., StalPers, J. A., 2001: Dictionary of the fungi. CABI Europe, Wallingford, UK.

KoL, E., 1956: Sur la microvégetation de la neige des montagnes de la Bulgarie I. Bulletin of Institute of Botany, Bulgarian Academy of Sciences 5, 377-384.

Kol, E., 1968: Kryobiologie I. Kryovegetation. In: Elster, J., OHLE, W. (eds.), Die Binnengewasser 24, 216. Schweizerbart'sche Verlagsbuchhandlung, Stuttgart.

KvíDEROVÁ, J., 2012: Research on cryosestic communities in Svalbard: the snow algae of temporary snowfields in Petuniabukta, Central Svalbard. Czech Polar Reports 2, 8-19.

LetCher, P. M., Powell, P. J., 2012: A taxonomic summary and revision of Rhizophydium (Rhizophydiales, Chytridiomycota). University Alabama, Tuscaloona.

Li, H., LiU, X., WANG, Y., Hu, H., Xu, X., 2009: Enhanced expression of antifreeze protein genes drives the development of freeze tolerance in an Antarctica isolate of Chlorella vulgaris. Progress in Natural Science 19, 1059-1062.

LuKAVsKÝ, J., 1970: Observation on some parasitic Chytridiomycetes. Archiv für Protistenkunde 112, 138-144.

LuKAVSKÝ, J., 1994: Algal flora of lakes in the High Tatra mountains (Slovakia). Hydrobiologia 274, 65-74.

Lukavský, J., CEPÁK, V., 2010: Cryoseston in Stara planina Mts. (Bulgaria). Acta Botanica Croatica 69, 163-171.

LukaVský, J., FurnadZhieva, S., NedBalová, L., 2009: First record of cryoseston in the Vitosha Mts., Bulgaria. Nova Hedwigia 88, 97-109. 
Novis, P. M., 2002: New records of snow algae for New Zealand, from Mt. Philistine, Arthur's Pass National Park. New Zealand. Journal of Botany 40, 297-312.

Novis, P. M., Hoham, R. W., Beer, T., Dawson, M., 2008: Two snow species of the quadriflagellate green alga Chlainomonas (Chlorophyta, Volvocales), ultrastructure and phylogenetic position within the Chloromonas clade. Journal of Phycology 44, 10011012 .

Pulz, O., Gross, W., 2004: Valuable products from biotechnology of microalgae. Applied Microbiology and Biotechnology 65, 635-648.

REMIAS, D., LÜTZ-MEINDEL, U., LÜTZ, C., 2005: Photosynthesis, pigments and ultrastructure of the alpine snow alga Chlamydomonas nivalis. European Journal of Phycology 40, 259-268.

RothSCHILD, L. J., 1990: Earth analogs for Martian life. Microbes in evaporites, a new model system for life on Mars. Icarus 88, 246-260.

StARMACH, K., KAWECKA, B., 1965: The yellowish-green snow in the valley. Limnological investigations in the Tatra mountains and Dunajec River Basin. Komitet Zgospodarowania Ziem Górskich 11, 75-80.

ŘEzanka, T., NedbalovÁ, L., Singler, K., CEPÁK, V., 2007: Identification of astaxanthin diglucoside diesters from snow alga Chlamydomonas nivalis by liquid chromatography - atmospheric pressure chemical ionization mass spectrometry. Phytochemistry 69, 479-490.

ŘEzANKA, T., NedBAlovÁ, L., Singler, K., 2008: Unusual medium-chain polyunsaturated fatty acids from snow alga Chloromonas brevispina. Microbiology Research 163, 373-379.

SchÜRCH, S. C., SchmidT, D. F., ZuLli, F., 2010: Use of an extract from snow algae in cosmetic or dermatological formulations. European Patent EP2260829.

SECKBACH, J. (ed.), 2007: Algae and cyanobacteria in extreme environments (Cellular origin, life in extreme habitats and astrobiology). Springer, Dordrecht.

STAUB, R., 1961: Ernährungsphysiologische Untersuchungen an der planktonischen Blaualge Oscillatoria rubescens DC. Schweizerische Zeitschrift für Hydrologie 23, 82-198.

Wang, B., Zarka, A., Trebst, A. V., BoussibA, S., 2003: Astaxanthin accumulation in Haematococcus pluvialis (Chlorophyceae) as an active photoprotective process under high irradiance. Journal of Phycology 39, 1116-1124.

Wharton, R. A., Mckay, C. P., Mancinelli, R. L., Simmons, G. M., 1989: Early Martian environments: The Antarctic and other terrestrial analogs. Advances in Space Research 9, 147-153.

WodenitscharofF, D. G., 1962: Hydrobotanische Untersuchungen über das Urdino-Kar (N-W Rila-Gebirge). Annuaire University Sofia, Faculty of Biology, Geology and Geography. 1. Biologie (Botanique) 54/55, 141-209. 